\title{
Social Inequalities in Obesity Persist in the Nordic Region Despite Its Relative Affluence and Equity
}

\author{
Maria Magnusson • Thorkild I. A. Sørensen • Steingerdur Olafsdottir • \\ Susanna Lehtinen-Jacks • Turid Lingaas Holmen • \\ Berit Lilienthal Heitmann • Lauren Lissner
}

Published online: 7 January 2014

(C) Springer Science+Business Media New York 2014

\begin{abstract}
Social inequalities in overweight and obesity (OWOB) have persisted in the affluent and reputedly egalitarian Nordic countries. In this review we examine associations between socioeconomic position (SEP) and OWOB, and secular trends in such associations. Determinants and possible causes of the relations are discussed together with opportunities to cope with OWOB as a public health problem. The findings show a persisting inverse social gradient. An interaction between SEP and gender is noted for adults in Denmark, Finland and Iceland and for children in Sweden. There are overall tendencies for increased inequality, however no consistent trend for an increased social gradient in OWOB.
\end{abstract}

M. Magnusson $(\bowtie) \cdot$ L. Lissner

Department of Public Health and Community Medicine, University of Gothenburg, Box 454, 40530 Gothenburg, Sweden

e-mail: maria.magnusson@allmed.gu.se

L. Lissner

e-mail: lauren.lissner@medfak.gu.se

T. I. A. Sørensen • B. L. Heitmann

Institute of Preventive Medicine, Bispebjerg and Frederiksberg

Hospital - Part of the Copenhagen University Hospital, Copenhagen, Nordre Fasanvej 57, 2000 Frederiksberg, Denmark

T. I. A. Sørensen

e-mail: TSOE0005@regionh.dk

B. L. Heitmann

e-mail: Berit.Lilienthal.Heitmann@regionh.dk

T. I. A. Sørensen

Novo Nordisk Foundation Center for Basic Metabolic Research, Faculty of Health and Medical Sciences, University of Copenhagen, Copenhagen, Denmark

\section{S. Olafsdottir}

Department of Food and Nutrition, and Sport Science, University of Gothenburg, Laroverksgatan 5, Box 320, 40530 Gothenburg, Sweden

e-mail: stina.olafsdottir@ped.gu.se
Reasons that increased inequality does not unequivocally mirror in a steepened social gradient in obesity may include methodological questions as well as societal efforts to counteract obesity. Multi-level efforts are needed to prevent OWOB.

Keywords Adolescents · Adults · BMI · Children · Denmark · Education · Egalitarian · Finland · Gender · Gini coefficient $\cdot$ Iceland $\cdot$ Income $\cdot$ Inequality $\cdot$ Nordic countries . Norway · Obesity · Obesogenic - Occupation - Overweight . Secular trends · Social gradient $\cdot$ Socioeconomic position .

S. Lehtinen-Jacks

School of Health Sciences (HES) Medisiinarinkatu 3, University of Tampere, 33014 Tampere, Finland

e-mail: susanna.lehtinen-jacks@uta.fi

e-mail: susanna.lehtinen-jacks@thl.fi

S. Lehtinen-Jacks

Nutrition Unit, National Institute for Health and Welfare, Mannerheimintie 166, 00280 Helsinki, Finland

\section{T. L. Holmen}

HUNT Research Centre, Department of Public Health and General Practice, Faculty of Medicine, Norwegian University of Science and Technology (NTNU), Forskningsveien 2, 7600 Levanger, Norway e-mail: turid.lingaas.holmen@ntnu.no

\section{B. L. Heitmann}

National Institute of Public Health, University of Southern Denmark, Odense M, Denmark 
Socioeconomic status $\cdot$ Sweden $\cdot$ Obesity $\cdot$ Social inequalities $\cdot$ Nordic region

\section{Introduction}

The occurrence of obesity in humans is associated with socioeconomic position (SEP). A trend towards an inverse social gradient, first documented in the USA [1, 2], has since then spread to most populations in the Western world [3, 4] and thereafter also to the poorer countries [5]. Reasons for this are not fully understood. Societal organization on a macro-level seems to matter. For example; a high degree of marketliberalism [6] has been suggested to increase the prevalence of obesity in the population. Inequality within countries seems to be positively associated with an inverse gradient between SEP and overweight and obesity (OWOB) [7].

The Nordic countries (Sweden, Denmark, Finland, Norway and Iceland, order by number of inhabitants) are affluent, highly regulated welfare states, and hence relatively egalitarian. Measured by the Gini coefficient (describing the distribution of income within a country) they are all among the top ten of the world; aiming at providing all citizens with basic education, food, health care, social support and economic protection when ill or unemployed (Table 1). For comparison; 2000-2011 the GINI-coefficient for the European Union rose from 29-30 [7, 8]. Relative poverty is another commonly used indicator of income dispersion within countries [9]. The Nordic countries, with the possible exception of Iceland, are also among those in Europe with the lowest prevalence of OWOB (Table 1) [10, 11].

In this review, we will assess the presence of social inequality in OWOB in the Nordic countries. Specifically, we will examine socioeconomic gradients in obesity among adults and children, differences between genders and between areas of different social status, and, to the extent possible, secular trends in the social gradient in each country. Finally, we will discuss the implications of the findings with regard to understanding the determinants and possible causes of the relations as well as to the opportunities to cope with OWOB as a public health problem.

\section{Gradients in Adults and Children, and Trends in the Gradients}

Sweden

There are no nationally representative objective data on prevalence of obesity in Swedish adults, but all available data point to a large increase in prevalence in the latter part of the twentieth century. High prevalence of obesity in socioeconomically disadvantaged groups in Sweden has also been observed consistently during this period.

An early example is from the 1968/9 baseline examination of the Population Study of Women in Gothenburg, where 38 and 50-year old women with more education were far less likely to be overweight or obese than those with middle and lower educational status [12]. This pattern has persisted to the present time (Fig. 1).

In a nationally representative sample surveyed by Statistics Sweden in 2004-5, only self-reported weight and height data are available. In this study, age-standardized mean BMI in both women and men was lower in those with at least 12 years of education compared to groups with less education, by circa 0.75 BMI units [13]. Around the same time, measured anthropometric data from the InterGene population-based survey in Western Sweden indicated that the prevalence odds ratio for obesity in the lower education category was 1.89 (1.37-2.60), or $8.1 \%$ in university educated subjects compared to $14.4 \%$ in the rest [14•].

The current social gradient in Swedish children seems to be consistent with that observed in adults. The only nationally representative and objectively measured survey of obesity in Swedish children is part of the WHO-COSI survey of 7-9 year olds. Using data on educational attainment on the area level,
Table 1 Data on population and markers of inequality in the Nordic countries. A Gini coefficient of zero expresses perfect equality and a Gini coefficient of 100 (on the percentile scale) expresses maximal inequality

\footnotetext{
${ }^{\text {a }}$ Self-reported data, response rate varying from 21 (Norway) to $63 \%$ (Denmark)
}

\begin{tabular}{|c|c|c|c|c|c|c|}
\hline \multicolumn{2}{|l|}{ Country } & Sweden & Denmark & Finland & Norway & Iceland \\
\hline \multicolumn{7}{|l|}{ Parameter } \\
\hline \multicolumn{2}{|l|}{ Population (million) } & 9.5 & 5.6 & 5.4 & 5.0 & 0.32 \\
\hline \multirow{3}{*}{\multicolumn{2}{|c|}{ Gini coefficient, Eurostat data [8] }} & 1997:21 & 1995:20 & 1996:22 & - & - \\
\hline & & $2001: 24$ & 2001:22 & $2001: 27$ & 2001:22 & $2004: 24.1$ \\
\hline & & $2011: 24.4$ & $2011: 27.8$ & 2011:25.8 & $2011: 27.8$ & 2011:23.6 \\
\hline \multirow[t]{3}{*}{ Relative poverty \% [9] } & 2009 & 13.3 & 13.1 & 13.8 & 11.7 & 10.2 \\
\hline & 2010 & 12.9 & 13.3 & 13.1 & 11.2 & 9.8 \\
\hline & 2011 & 14.0 & 13.0 & 13.7 & 10.5 & 9.2 \\
\hline \multicolumn{2}{|c|}{ Prevalence of obesity, $\%{ }^{a}[10]$} & 10.2 & 12.0 & 14.0 & 8.7 & 17.8 \\
\hline
\end{tabular}


Fig. 1 Prevalence of overweight in 38- and 50-year-old women from the Population Study of Women in Gothenburg, Sweden from $1968 / 69$ to $2004 / 5$. There was no interaction between time and education in relation to overweight

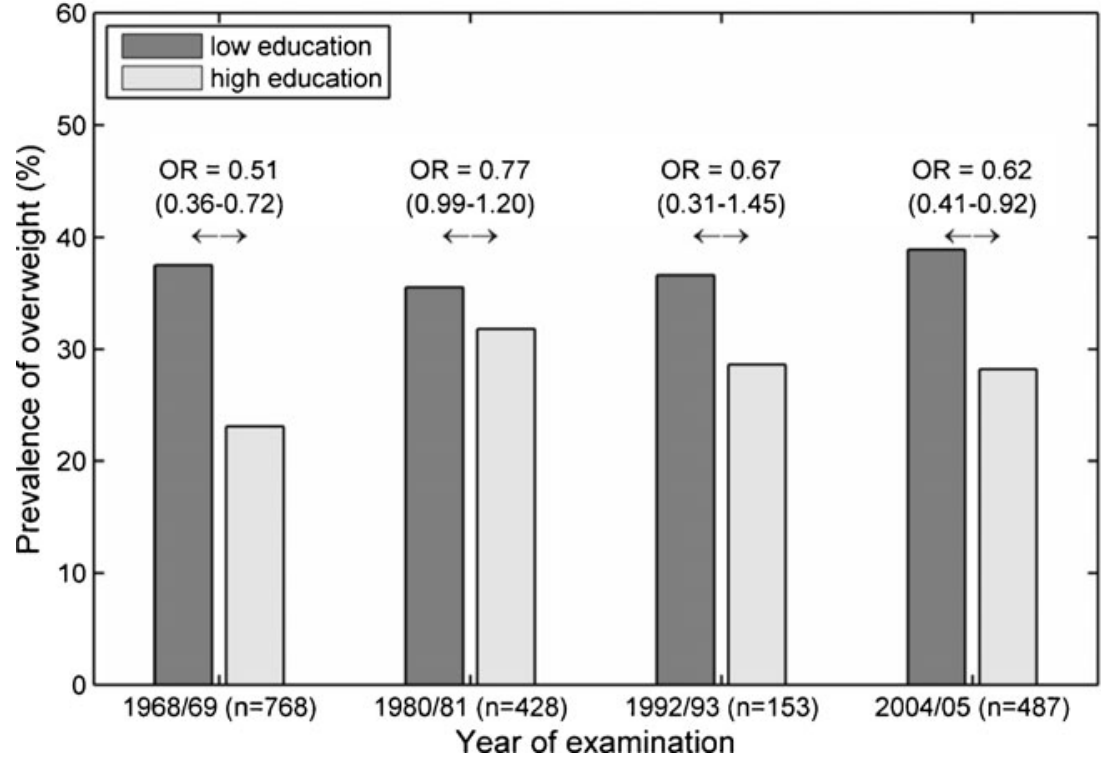

OWOB respectively were approximately 2 and 3 times more prevalent in areas with lower compared to higher area-level education areas [15]. An urban-rural gradient was also observed, which was to a large extent explained by lower educational attainment in the rural areas. Using individual level data from parents of the same children, the education gradient for obesity was confirmed, with a somewhat larger effect of paternal then maternal education (OR 6.6 for fathers and 4.8 for mothers with low education, relative to more than 12 years of education [16]. In the IDEFICS western Sweden study of 2-8 year children, other socioeconomic indicators showed stronger associations than parental education: specifically, high household income and parental occupational position were both highly protective for OWOB [17].

There are also a few studies investigating whether the inverse socioeconomic gradient as described above has been widening or narrowing in recent decades. As illustrated in Fig. 1 the gradient has been relatively stable in middle-aged western Swedish women over the past few decades, with no evidence of a significant shift over time. At baseline (1968/69) as well as at the latest examination point (2004/05) women with more education were far less likely to be overweight or obese than those with middle and lower educational status. There was no interaction between time and education in relation to overweight, suggesting that the slope of the gradient did not change significantly between 1968 and 2005. In contrast to this local study of women, a nationally representative comparison of Statistics Sweden's questionnaire surveys conducted in the early 1980s and the late 1990s gave some indication of a narrowing of the education gradient for overweight in younger adults aged 25-44 years, but a stable inverse gradient at ages 45-64 [18]. However, a population based cohort of elderly residents in western Sweden indicated that the gradient was getting steeper between 1971-2000, with greatest obesity prevalence increases observed in 70 year olds with basic education only [19]. Studies in 10 year old children have also given inconsistent answers to the question whether the gradient was increasing. In female cohorts from Stockholm and Gothenburg, studied in 1994-5 and 1999-2000, there was no evidence that the inverse gradient was changing in girls [20,21]. Interestingly, there was a trend towards lower BMIs during this period in girls from all social groups. In boys, the picture was less consistent, with those from lower income areas in Stockholm showing the greatest prevalence increases, i.e. steeper gradient, but this was not the case in Gothenburg [20-22].

\section{Denmark}

Studies document that already in the early 2000s almost 1 in 5 of all Danish adults aged 30-60 years were obese, compared to less than 1 in 10 just 20 years earlier [23]. However, there are trends suggesting increase as well as decrease among subsegments of the population. Measured heights and weights among adults aged $20+$ years, from the greater Copenhagen County, showed that while the overall Danish trend for obesity prevalence markedly increased from the beginning of 1960, the trends over the following 40 years were different among men and women and for different age- and birth-cohorts. Indeed, there was only little indication of an increasing trend in obesity prevalence for premenopausal, whereas among postmenopausal women and men of all ages, the prevalence of obesity was increasing [24]. These data suggested stable or even declining obesity prevalence among the premenopausal Danish women. The Danish trends from mid-1960s to mid1990s were paralleled by similar findings for women in the other Nordic countries, suggesting common conditions operating, i.e. the rate of entrance into the paid labor force, which 
took place much earlier and at a higher rate than among women from most other countries. Marked differences in obesity occurrence still exist between employed and unemployed women [25], as well as between those with longer and shorter education (Fig. 2a) [26]. Another Danish study showed that young men with shorter education (7-9 years) were more overweight than those with high school degrees [27]. Finally, another study including subjects selected at random from the civil registration system concluded that education was the dimension most consistently associated with BMI and obesity, particularly for women, indicating the importance of cultural capital for weight status [28].

Danish children from lower SEP groups run a greater risk of developing overweight and obesity. This has been the conclusion from several studies including a recent one, from among a total of 1656 children followed between 1996 and 2003, and selected to be a representative sub-sample of children from the two major cities of Denmark: Copenhagen and Aarhus. The study used measures of height and weight, taken at the school health examination as the children were in 9th grade, in 23 municipalities. The study found a higher prevalence of obesity among those children that came from low SEP families, and the inverse social gradient in overweight became steeper with age for girls while it emerged for boys in late adolescence [29]. Another study among 8694 children, also measured during the 9th grade school health examinations in 2007-2009, found higher obesity prevalence among children from more disadvantaged areas. In this study, municipalities characterized as being overall high or low socioeconomic status areas, based on factors such as number of unemployed, uneducated and low income families, had more overweight children than municipalities with high socioeconomic status, prevalence varying between 15.3 and $33.5 \%$ [30]. Finally, health check-ups among almost 1800 3-year olds living in the city of Aalborg in 2002, showed that already at this young age, children from low SEP families (one or more parents being unskilled workers or unemployed/disabled pensioners/students) were more overweight and obese [31].

Not much data is available that can document the more recent development in obesity rates as a function of SEP. However, data following trends among adults until 2006 suggests a diverging development for men and women. In fact, among overweight women, those with some education (professional education, high school or more) seem to have experienced some recent decline in prevalence, while this has not been observed for women with primary school only. Among men, those with some education seem to have experienced a levelling off in prevalence of OWOB since 2000, while a significant decline was seen for those with low education (Fig. 2b) [26]. The results suggest that whether the gradient is getting steeper or flatter among Danes depends on both socioeconomic position and gender.
Finland

Mean BMI and prevalence of OWOB increased in Finland since the 1970s in men, whereas women actually became slimmer during the 1970 s and started gaining weight thereafter [32-34]. In 2007, $22 \%$ of the working-aged men and $20 \%$ of the working-aged women were obese [34]. According to the most recent information, the prevalence of OWOB among Finnish adults may have been plateauing during the past 10 years (2002-2012) [35].

Higher BMI and OWOB in the Finnish population are more common in the lower SEP groups (Fig. 3a and b). An inverse gradient in mean BMI according to education was already evident in women in the first available survey in 1972, whereas in men the gradient emerged during the next 5 years [32]. Mean BMI or OWOB also differed by occupational status [33], employment status [36], and income $[36,37 \cdot \bullet]$, especially in women. The typical educational gradient was observed also among the older population [38]. BMI and OWOB were more common in rural than urban areas across Finland [39, 40].

The prevalence of OWOB has increased also among Finnish adolescents [41, 42]. The only study with comparative information in OWOB in younger Finnish children found no increase in the prevalence of OWOB in pre-school children from the 1970s to the 2000s [42]. In 2007-2009, approximately $15 \%$ of pre-school girls and $10 \%$ of boys were overweight or obese (IOTF criteria), while the respective proportions for school-aged children and adolescent were $20 \%$ in girls and $21 \%$ in boys [43].

Regarding adolescents, an inverse association between SEP and prevalence of OWOB has been observed in both genders, according to several indicators representing family SEP (parental education, occupational status, and employment status), the adolescent's own social position (school achievement, school attendance) or the family's material affluence [41, 44]. Data on associations between SEP and OWOB among children (younger than adolescents) are scarce. A similar rural-urban difference as in adults has been observed in children and adolescents [41, 42].

Three large population-based studies in working-aged adults ([32-34, 37••, 45] one in older people [38], and one in adolescents [41] have examined the associations between SEP and BMI or OWOB across time in Finland. Results from the Mini-Finland survey and the comparative Health 2000 Survey [45] suggest that the educational gradient in obesity diminished during the 1980s and 1990s especially in men, because of a prominent increase in the prevalence of obesity in men with the highest education. The same was not observed in the FINRISK study, where the educational gradient in BMI was observed to have widened during the 1970s and 1980s $[32,33]$, but stayed stable during the 1990s or 2000s [33, 34] (Fig. 3). Regarding occupation, the trends in BMI were similar 
Fig. 2 a (women) and b (men) The proportion of men and women from the greater Copenhagen area, who in the years between 1978 and 2006 had a BMI above $25 \mathrm{~kg} / \mathrm{m}$. (With permission from: Jensen HN GC, Jørgensen T.

Udvikling i risikofaktorer for hjerte-karsygdom i Vestegnskommunerne 19782006. s. 31. Glostrup, Danmark 2008) [26]. After 1983, participants were divided into three categories based on the duration of their vocational training. Before 1983 it was not possible to differentiate the length of the vocational training, and they were categorized with or without vocational training, only

Fig. $3 \mathbf{a}$ (men) and $\mathbf{b}$ (women) Data from 25- to 64-year-old participants of the national FINRISK surveys, Finland. The prevalence of obesity (BMI $>30 \mathrm{~kg} / \mathrm{m}^{2}$ ) decreased systemically with increasing level of education both in men and women [34]

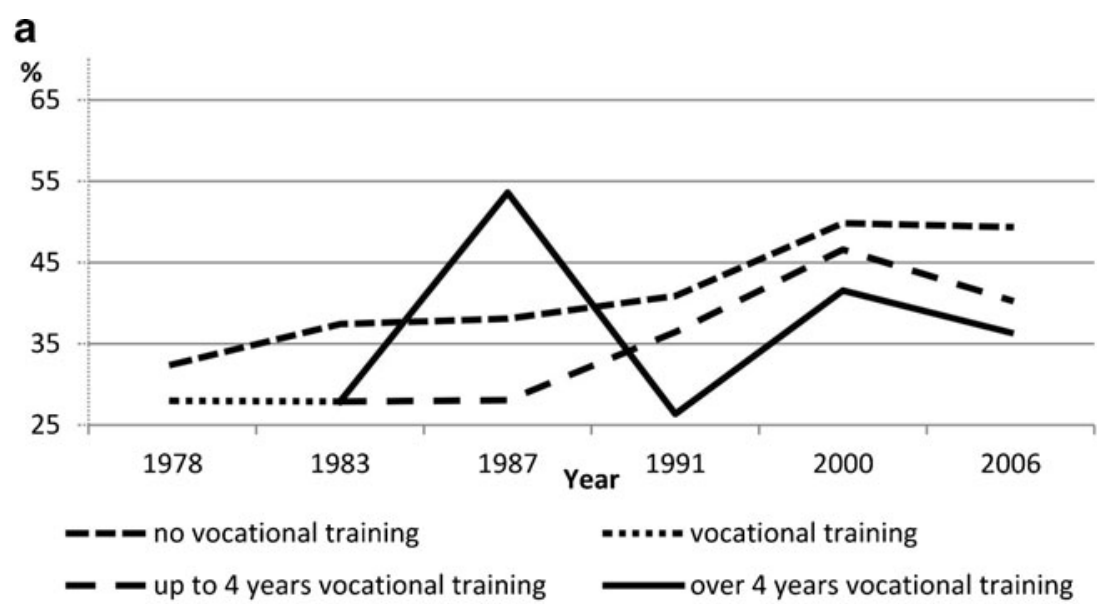

b

$\%$

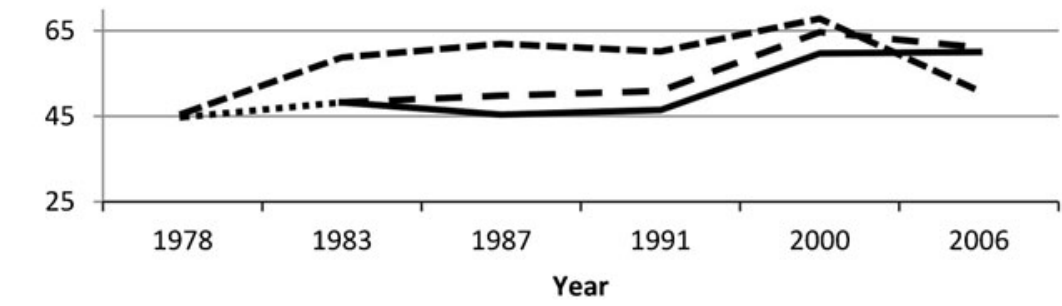

-ーー no vocational training

......-vocational training

- - up to 4 years vocational training

over 4 vocational training

a

Low

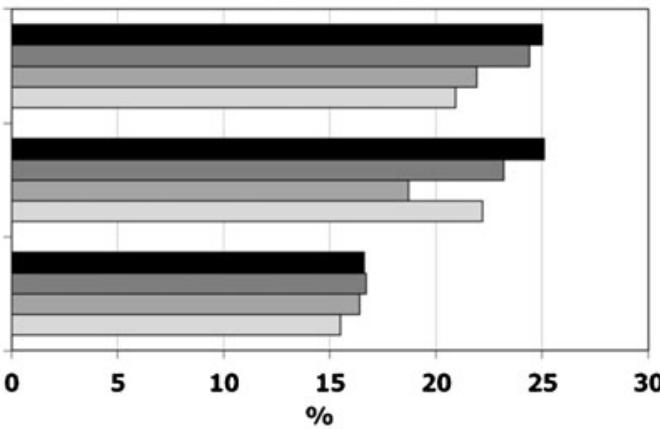

- 2007

$\square 2002$

Medium

$\square 1997$

$\square 1992$

b

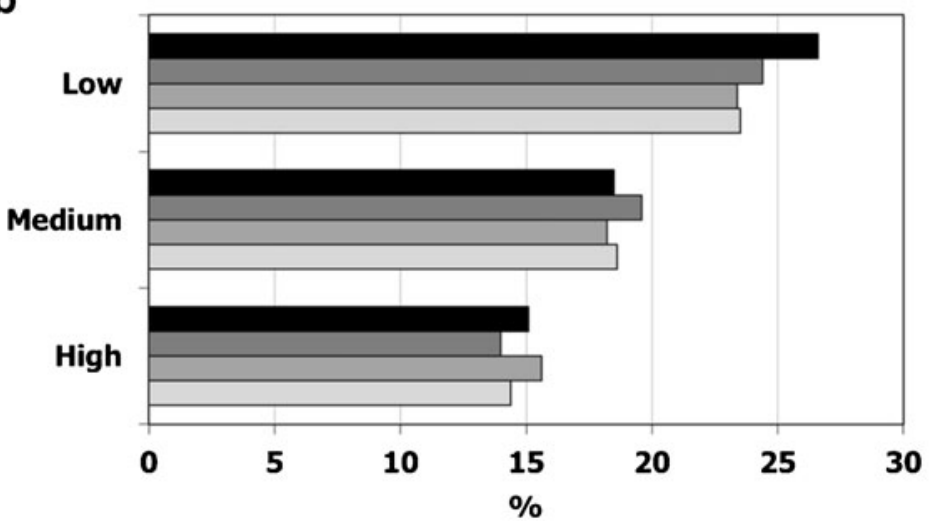

2007 
in all occupational groups in women, while the increase was greatest among retired and unemployed men between 1982 and 1997 [33]. The Finnish adult health behavior survey did not show any overall change in the educational or incomerelated differences in BMI either, between 1978 and 2002 [37••]. However, education and income interacted with each other in men, such that the most prominent increase in BMI across the study period took place in high income men with low education and in low income men with high education [37••]. Among the older people, the educational differences in obesity stayed at approximately constant level, even if a slight decrease in the disparity was observed in women [38]. Among adolescents, there were some fluctuations in the SEP gradient in OWOB between subsequent surveys (the Adolescent Health and Lifestyle Survey, repeated biennially in 19792005), but in general the gradient remained rather stable, regardless of whether the SEP was measured by familial or adolescent's own socioeconomic position, or by the urbanization level of the place of residence [41].

\section{Norway}

Studies from different parts of Norway have shown an increase in obesity in all age groups from the late 1960s, more so in men compared to women [46-49]. In women a decline in obesity (BMI $\geq 30$ ) was actually seen from the 1960 s until the late 1970s before it again increased [46]. In the HUNT study, Nord-Trøndelag county, including 90,000 adults 20 years and older, obesity measured in 1984-86, 1995-97 and 2006-08 increased from $7.7 \%$ to $14.4 \%$ and $22.1 \%$ in men and from $13.3 \%$ to $18.3 \%$ and $23.1 \%$ in women [48]. The increase in weight has been observed at all social levels, but a higher prevalence of obesity has constantly been found in the more socioeconomically disadvantaged groups at all time points $[46,49,50 \bullet, 51]$. Some studies have reported larger educational inequalities in BMI in women compared to men [51], others not. In the most recent HUNT survey (2006-2008) the prevalence ratio in educational inequalities (low to high) of obesity was 1.9 in men and 1.6 in women [50••]. Educational inequalities have mostly been focused on, but differences in obesity prevalence have also been observed between people living on the east or west side of the capital city, Oslo and between cities and rural districts $[52,53]$.

Overweight and obesity has increased since the 1970s also among children and adolescents from 4 to 19 years of age [54-60]. The growth study in Oslo (2012) found $3.6 \%$ of 8 years old children to be obese [52], while the YoungHUNT3 Survey (2006-08) found $4 \%$ of girls and $5.6 \%$ of boys aged $13-16$ years and $5 \%$ of girls and $7.5 \%$ of boys aged 17-19 years to be classified as obese using the IOTF recommended cut-points for age and gender [60]. The same social gradient of obesity as in adults is also reported in children and adolescents [52, 61-66]. Lower parental education level has clearly been associated with higher prevalence of obesity in studies both from the larger cities, Oslo and Bergen [61, 62, 66] and also more rural areas [57, 63-65]. In the Bergen Growth Study and the Young-HUNT Study higher parental education was found to be associated with a less obesogenic lifestyle [66, 67]. Obesity in adolescence has been associated with plans for lower education. A higher prevalence of obesity is observed in rural areas compared to more densely populated cities and residential area in Oslo. Differences in education and economy may partly explain this [68].

In three waves (1974-78, 1977-83 and 1985-88) The Norwegian Counties Study including 48,000 middle aged men and women in three counties, also focused on trends in educational inequalities in cardiovascular risk factors [51]. For BMI there was a tendency to a decrease in inequality for men while for women an increase. The same tendency was not verified studying differences in obesity in 40-42 aged men and women in eight counties between 1994-96 and 1997-99 [49]. The HUNT Study compared the three waves of 1984 86, 1995-97 and 2006-08 regarding changes in socioeconomic differences in obesity in 30-69 years old men and women including over 40,000 people in each wave [50••]. In this study relative socioeconomic inequalities in obesity measured by level of education did not show a clear trend (men: 1.9, 1.7, and 1.9; women: 1.8, 1.8, and 1.6). However, the absolute prevalence differences in obesity between people with primary and tertiary education increased from 4.5 to $14 \%$ among men and from 6.2 to $10 \%$ among women in $1984-86 \mathrm{com}$ pared to 2006-08 (Fig. 4a and b). Similar studies of trend in gradients are not found for children or adolescents.

\section{Iceland}

The prevalence of obesity has increased in Iceland since the 1980s [69] and is by the Nordic Monitoring report considered to be higher than in any other Nordic country (Table 1) [10]. In 1990 , less than $10 \%$ of $18-80$ years were obese, which has increased to about 1 in 5 in 2007 [69]. According to the most recent National Nutrition Survey [70] the prevalence of overweight was $38 \%$ and obesity $21 \%$ or total of $59 \%$ in the age group 18-80 years. The National Nutrition Survey (selfreported by telephone) also confirms that obesity is more common among men $(22.7 \%)$ than women $(19.3 \%)$. Comparison with data from the Reykjavik study by the Icelandic Heart Association (repeated objective measurements within the capital area) could indicate underreporting as obesity for men was $27.5 \%$ and $23 \%$ for women in 2007 [69]. A population-based study of 15,000 women $18-45$ years old in 2003-2004 [71] revealed that living outside the capital area and not having university education was associated with increased risk of obesity (OR of being obese living outside capital area 1.66, $95 \%$ CI 1.50-1.83, and having less than 
Fig. 4 a Age-adjusted prevalence of obesity (BMI $\geq 30 \mathrm{~kg} / \mathrm{m}^{2}$ ) by educational level in men 30 69 years from three surveys (1984-86, 1995-97, and 2006-8) of the HUNT study, Norway [50••]. b Age-adjusted prevalence of obesity (BMI $\geq 30 \mathrm{~kg} / \mathrm{m}^{2}$ ) by educational level in women 30 69 years from three surveys (1984-86, 1995-97, and 2006-8) of the HUNT study, Norway [50••] a

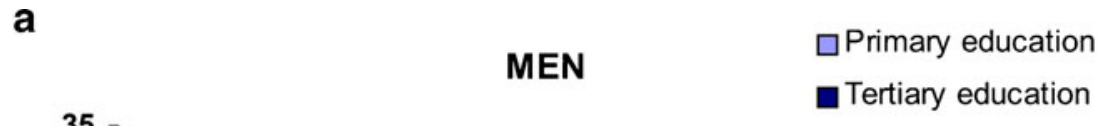

b

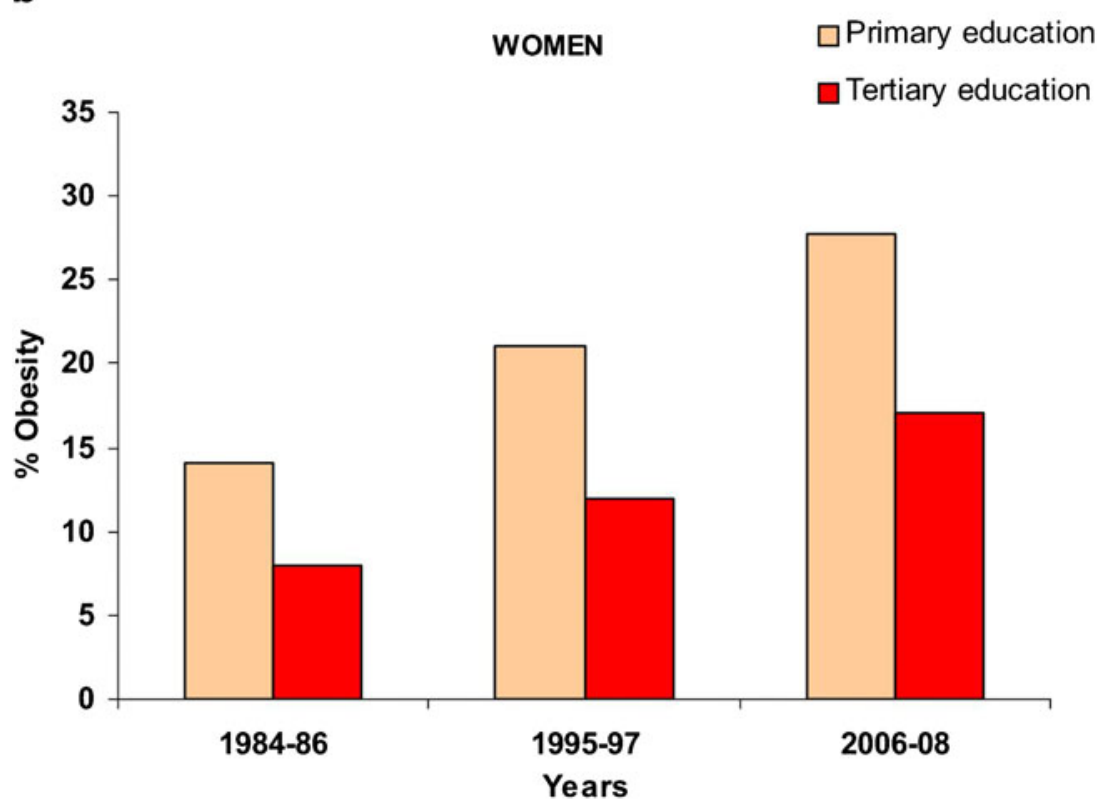

university education $1.53,95 \%$ CI 1.36-1.71). The proportion of obese women was more than double within the group who had finished elementary school compared to the group with a university education. According to the same study, the prevalence of obesity for women 18-45 years old was $13 \%$ within the capital area compared to $21 \%$ outside the capital area. The difference between weight status within and outside the capital area could not be explained by different education between the areas. In the two most recent National Nutrition Surveys $[70,72]$ the urban-rural gradient has been found, however only for women and for total OWOB.

According to the Nordic Monitoring report [10] the prevalence of overweight in children 7-12 years was
$15.1 \%$ and of obesity $3.5 \%$, and did not significantly differ from the other Nordic countries. Regular objective measurements of 9-year-old school children by the Primary Health Care of the Capital Area indicate that the increase in childhood OWOB seen in the last decades has now halted [73]. Inverse associations have been found between OWOB in young adults, and parents' education [74••]. According to the Nordic monitoring report [10] the number of children in normal weight increased with increased educational level of the parent. This trend was significant in Iceland. The urban-rural gradient has also been found for adolescents, in a study based on self-reported data from two cross-sectional 
population-based samples of 14- and 15-year-old pupils in 2000 and 2009, from the "Youth in Iceland" surveys [75]. Overweight and obesity increased for both boys and girls between the study years. Mean BMI and prevalence rates of OWOB were higher in rural areas than urban areas in both study years. An unpublished undergraduate thesis (Randversdottir LB. 2011. Are children and adolescents getting heavier? In Icelandic) has studied the urban-rural gradient in OWOB with similar conclusions as the studies on adults: The prevalence of OWOB was higher outside the capital area than within it and this gap was persistent between the survey years 2006 and 2010 .

Eidsdóttir and colleagues [74••] have analyzed data from repeated population-based, cross-sectional surveys from cohorts of 16 to 20 year olds in 1992, 2004, 2007 and 2010 within the national survey Youth in Iceland. According to self-reported data on height and weight, the prevalence of OWOB increased across three subgroups of parental education level. The probability of OWOB across all years was consistently highest for youths with parents in the low-education category. The inverse SEP gradient in OWOB trends between parental education backgrounds became steeper over time with an exception for boys in association with fathers' education, where the net increase in OWOB was nearly similar in all education subgroups (Fig. 5a and b).

\section{Secular Trends in Different Groups and Development of Inequality}

Most findings point to an increase for all SEP groups in OWOB in the Nordic region during the last decades of the twentieth century. As for more recent development of the SEP gradient in obesity, data show inverse social gradients that are not consistently getting larger.

Results from Denmark suggest an interaction between SEP and gender. For Swedish and Norwegian adults, data on associations between social gradient and gender are mixed. In Norway the absolute difference in prevalence between low and high educational groups have been found to increase over the years, more so in men than women. In both Denmark and Finland the inverse social gradient has in general been stronger in women than in men, and the same seems to be true for Iceland.

For children, the gradient seems to be increasing more in boys than in girls, however in Finland the gradient seems similar in both genders. No significant trends are reported from Denmark while data from Iceland show a social gradient that is getting steeper over time. Finnish adolescents show a rather stable gradient between 1979 and 2005. Other reports from the developed world point at a social gradient that is stable [76] or getting steeper $[7,77]$.

\section{Methodological Considerations}

There are various measures of SEP (Table 2); most commonly education, occupational status and income, of which education is the most commonly used in the studies cited in this review. The indicators have different backgrounds and implications [78], are differentially associated with weight status [76] and may interact with each other [37••]. Nevertheless they are often used interchangeably. This contributes to difficulties in understanding reasons behind the social gradients. Also, changes in associations over time can be blurred by changed significance of the categories. For example; the implications of graduating from high school changed during the latter part of the last century, from being a significant careerstep into a necessary condition for entering the labor market.

Also, an increasing gradient may also be defined in different ways. For instance, in Norway the absolute difference in prevalence between higher and lower educational groups increased but the relative gradient was stable, with an approximately doubled prevalence ratio in the less educated groups at both time points (Fig. 4a and b).

Non-participation in epidemiological studies leads to bias by lower participation from people with obesity (especially girls and women) [79], young men, people of foreign origin and people with low education [14•]. The problem of nonparticipation has worsened, thus affecting the comparability of data from studies at different time-points. A possible effect of a growing number of study dropouts is that obese people with low education are underrepresented to a higher extent in later studies which could bias the conclusions in various directions.

This review includes both measured and self-reported data. In the Western culture, self-reported weight and height generally lead to an underestimation of BMI [80] (exemplified above in the Icelandic section). Even though the correlations between measured and self-reported data across the populations are quite high, it leads to a considerable misclassification of individuals in the tails of the distributions, e.g. with OWOB, and hence a considerable underestimation of the prevalence of OWOB. Such errors may also include interactions between SEP and gender [81] as well as changes over time [82]. In a study done in Stockholm 1984-1985, it was more common for obese women than for obese men to underreport their weight. In the same study, self-reported measures underestimated SEP differences in height and underweight for men and in obesity for women [81]. A more recent review shows a pattern where self-reported data for women overestimated the SEP differences [83]. Also, it is well known that cultural values differ regarding thinness and overweight [84]. It seems probable that such attitudes change over time in any given society which would contribute to the change in validity of self-reported measures of weight and height over time. 
Fig. 5 a and $\mathbf{b}$ Trends in prevalence of overweight and obesity for 16- to 20-year-old Icelandic adolescents by gender and parental level of education in 1992, 2004, 2007, and 2010. Adolescents with low-educated mothers were consistently overrepresented among those with OWOB across four survey years. The gradient OWOB between the high- and loweducated subgroups increased over time. (With permission from: Eidsdottir S, Kristjansson A, Sigfusdottir ID, Garber CE, Allegrante JP. Secular trends in overweight and obesity among Icelandic adolescents: do parental education levels and family structure play a part? Scandinavian journal of public health. 2013;41(4):384-91) [74••]

\section{a}

Boys

Girls

Mothers education level

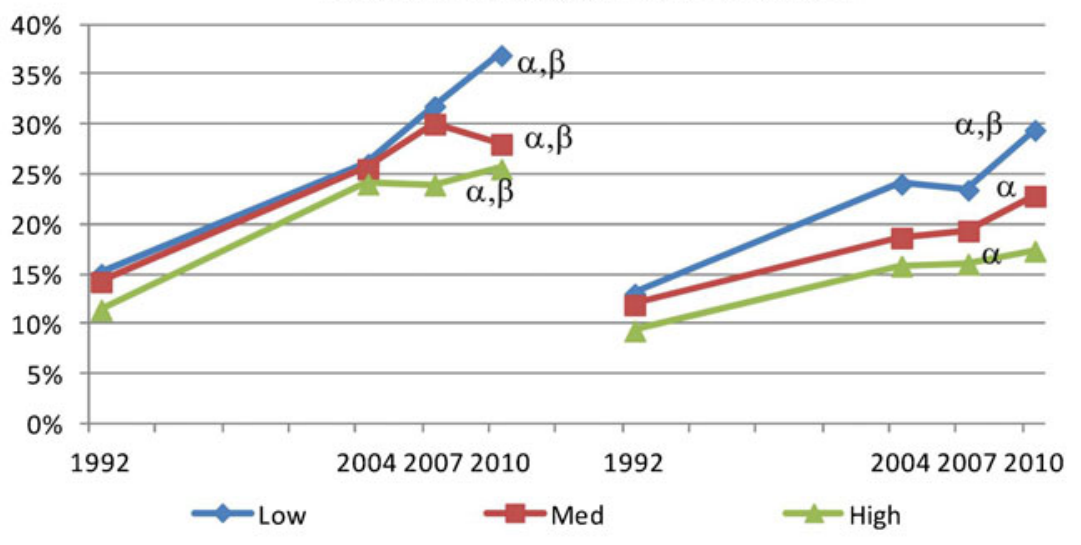

b

Boys

Girls

\section{Fathers education level}

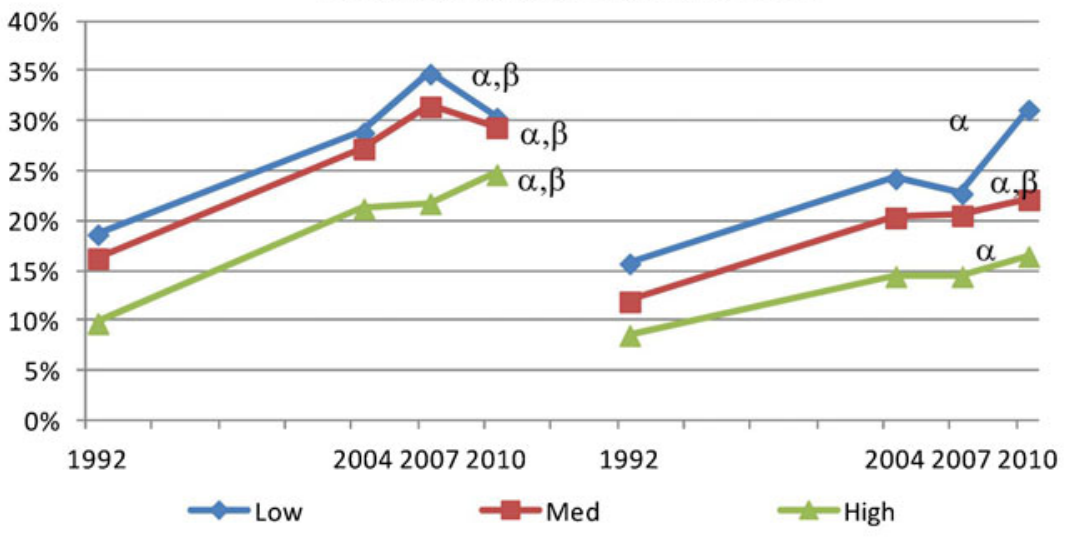

$\alpha=$ significant linear trend; $\beta=$ significant curvilinear trend.

\section{Interpretations of the Findings}

Having made these reservations for methodological shortcomings, we note that the social gradient in obesity is present in the Nordic countries in spite of their relative affluence and equity, that the gradient seems to have remained rather stable over time, and that different SEP-groups have had a similar relative increase in the prevalence of OWOB. However, the absolute differences in prevalence of obesity between the low and the high educational groups may have increased, as seen in the HUNT study from Norway.

Causes behind the gradient may be others than those that have made the prevalence rise in the whole population. It may also be that (some) factors do affect the whole population, but strike even harder in strata with low SEP. Reasons for this could be that people with more resources have greater potential to avoid adverse effects of certain features of modern society [85]. For example; education probably increases critical consciousness, which is important given the impact and amount of advertisement for energy dense food [86]. Size of income influences freedom of choice concerning food and leisure activities. Data from the Nordic region [87] as well as from other countries in the Western world [88] show that access to healthy food is limited for those with low income. Also, food with high energy density has become cheaper and thus easily available for people with low assets - making food with low energy density relatively more expensive. It is possible to construct a relatively healthy menu at a low cost, but not to make it diverse enough over time to be a realistic alternative [89]. Many opportunities for physical activity also cost money. Thus, given that food and physical activity are assumed to be important agents in the etiology of obesity, trends in associations between income and obesity are dependent on fluctuations in income levels, prices of healthy (and unhealthy) foods as well as fees for sports facilities.

Other explanatory factors behind the social gradient include stress, which can be increased in low social strata due to a "clustering and accumulation of psychological 
Table 2 Assessments of socioeconomic position and types of data on anthropometry, in papers cited

\begin{tabular}{|c|c|c|c|c|}
\hline \multirow[t]{2}{*}{ Paper } & \multicolumn{2}{|l|}{ Variables used to assess SEP } & \multicolumn{2}{|l|}{ Anthropometry } \\
\hline & Assessments on the individual level & Assessments on area level & Measured/reported & Indicator \\
\hline (Rasmussen LB, Andersen LF et al. 2012) [10] & $\begin{array}{l}\text { Education } \\
\text { Parental education } \\
\text { Urban/rural }\end{array}$ & & Self-reported & $\begin{array}{l}\text { BMI } \\
\text { Overweight and obesity }{ }^{\mathrm{a}, \mathrm{b}}\end{array}$ \\
\hline (Strandhagen, Berg et al. 2010) [14•] & $\begin{array}{l}\text { Education } \\
\text { Economic buffer } \\
\text { Economic imbalance } \\
\text { Employment status }\end{array}$ & & Measured & $\begin{array}{l}\text { Waist/hip ratio } \\
\text { Obesity }^{\mathrm{a}}\end{array}$ \\
\hline (Sjöberg, Moraeus et al. 2011) [15] & & $\begin{array}{l}\text { Urban/rural } \\
\text { Parental education }\end{array}$ & Measured & $\begin{array}{l}\text { Overweight }{ }^{\mathrm{b}} \\
\text { BMI SDS }\end{array}$ \\
\hline (Moraeus, Lissner et al. 2012) [16] & & $\begin{array}{l}\text { Urban/rural } \\
\text { Parental education }\end{array}$ & Measured & $\begin{array}{l}\text { Overweight } \\
\text { BMI SDS }\end{array}$ \\
\hline (Bammann, Gwozdz et al. 2013) [17] & $\begin{array}{l}\text { Parental education, } \\
\text { occupational } \\
\text { status and income }\end{array}$ & & Measured & Overweight and obesity ${ }^{\mathrm{b}}$ \\
\hline (Lissner, Johansson et al. 2000) [18] & Education & & Self- reported & Overweight and obesity $^{a}$ \\
\hline (Eiben, Dey et al. 2005) [19] & Education & & Measured & $\begin{array}{l}\text { Waist circumference, Waist/hip } \\
\text { ratio } \\
\text { Overweight and obesity }^{\mathrm{a}}\end{array}$ \\
\hline (Sundblom, Petzold et al. 2008) [20] & & Parental income & Measured & Overweight and obesity ${ }^{\mathrm{b}}$ \\
\hline (Sjöberg, Lissner et al. 2008) [21] & Parental education & & Measured & Overweight and obesity ${ }^{\mathrm{b}}$ \\
\hline (Magnusson, Sjöberg et al. 2011) [22] & & $\begin{array}{l}\text { Parental income and } \\
\text { education }\end{array}$ & Measured & $\begin{array}{l}\text { BMI, BMI z-score } \\
\text { Overweight and obesity }^{\text {b }}\end{array}$ \\
\hline (Heitmann, Stroger et al. 2004) [24] & $\begin{array}{l}\text { (studying gender and } \\
\text { trends over time) }\end{array}$ & & Measured & BMI, Overweight and obesity ${ }^{\mathrm{a}}$ \\
\hline (Sundhedsstyrelsen 2011) [25] & $\begin{array}{l}\text { Education } \\
\text { Employment status }\end{array}$ & & Self-reported & Overweight and obesity $^{\mathrm{a}}$ \\
\hline (Jensen HN 2008) [26] & Education & & Measured & Overweight and obesity $^{a}$ \\
\hline (Larsen, Lund et al. 2011) [27] & $\begin{array}{l}\text { Parental occupational } \\
\text { status at birth } \\
\text { Education at age } 20\end{array}$ & & Measured & $\begin{array}{l}\text { BMI } \\
\text { Overweight and obesity }\end{array}$ \\
\hline (Groth, Fagt et al. 2009) [28] & $\begin{array}{l}\text { Education } \\
\text { Employment status } \\
\text { Occupational status } \\
\text { Income }\end{array}$ & & Self-reported & $\begin{array}{l}\text { BMI } \\
\text { Obesity }^{\mathrm{a}}\end{array}$ \\
\hline (Krue and Coolidge 2010) [30] & & $\begin{array}{l}\text { Education, Income } \\
\text { Employment status }\end{array}$ & Measured & $\begin{array}{l}\text { BMI } \\
\text { Overweight and obesity }\end{array}$ \\
\hline (Aarup, Sokolowski et al. 2008) [31] & $\begin{array}{l}\text { Parental employment } \\
\text { status and occupational } \\
\text { status }\end{array}$ & & Measured & Overweight and obesity $^{\mathrm{a}}$ \\
\hline (Pietinen, Vartiainen et al. 1996) [32] & Education & & Measured & BMI, Overweight and obesity ${ }^{\mathrm{a}}$ \\
\hline (Lahti-Koski, Vartiainen et al. 2000) [33] & $\begin{array}{l}\text { Education, Occupational } \\
\text { status }\end{array}$ & & Measured & BMI, Overweight and obesity ${ }^{\mathrm{a}}$ \\
\hline (Lahti-Koski, Harald et al. 2012) [34] & Education & & Measured & $\begin{array}{l}\text { Waist circumference, WHtR, } \\
\text { BMI, Obesity }\end{array}$ \\
\hline (Sarlio-Lahteenkorva and Lahelma 1999) [36] & $\begin{array}{l}\text { Employment status, } \\
\text { Income }\end{array}$ & & Self-reported & Overweight and obesity $^{a}$ \\
\hline (Prättälä, Sippola et al. 2012) [37••] & $\begin{array}{l}\text { Education } \\
\text { Income }\end{array}$ & & Self-reported & BMI \\
\hline (Sulander, Uutela 2007) [38] & Education & & Self-reported & Obesity \\
\hline (Jokela, Kivimäki et al. 2009) [39] & Urban/rural & Urban/rural & Measured & BMI, Overweight and obesity ${ }^{\mathrm{a}}$ \\
\hline (Lahti-Koski, Taskinen et al. 2008) [40] & Urban/rural & & & $\begin{array}{l}\text { Waist circumference, WHR, } \\
\text { Obesity }{ }^{\mathrm{a}} \text {, }\end{array}$ \\
\hline (Kautiainen, Koivisto et al. 2009) [41] & $\begin{array}{l}\text { Parental education, } \\
\text { occupational status } \\
\text { and employment status } \\
\text { Adolescent's personal } \\
\text { social position (school } \\
\text { achievement or } \\
\text { school attendance), } \\
\text { Urban/rural }\end{array}$ & & Self-reported & Overweight and obesity ${ }^{b}$ \\
\hline (Vuorela, Saha et al. 2011) [42] & & Urban/rural & Measured & BMI, Overweight and obesity ${ }^{\mathrm{b}}$ \\
\hline (Koivusilta, Rimpelä et al. 2006) [44] & $\begin{array}{l}\text { Parental education, } \\
\text { occupation status } \\
\text { and employment } \\
\text { status Adolescent's }\end{array}$ & & Self-reported & Overweight and obesity ${ }^{\mathrm{b}}$ \\
\hline
\end{tabular}


Table 2 (continued)

\begin{tabular}{|c|c|c|c|c|}
\hline \multirow[t]{2}{*}{ Paper } & \multicolumn{2}{|l|}{ Variables used to assess SEP } & \multicolumn{2}{|l|}{ Anthropometry } \\
\hline & Assessments on the individual level & Assessments on area level & Measured/reported & Indicator \\
\hline & $\begin{array}{l}\text { personal social position } \\
\text { (school achievement) } \\
\text { Family's material affluence }\end{array}$ & & & \\
\hline Lahti-Koski, Seppänen-Nujten et al. 2010 [45] & Education & & Measured & $\begin{array}{l}\text { BMI } \\
\text { Obesity }^{\mathrm{a}}\end{array}$ \\
\hline (Meyer and Tverdal 2005) [46] & Education & & Measured & $\begin{array}{l}\text { BMI } \\
\text { Overweight and obesity }\end{array}$ \\
\hline (Tverdal 2001) [49] & Education & & Measured & Obesity $^{\mathrm{a}}$ \\
\hline (Strand and Tverdal 2006) [51] & Education & & Measured & BMI \\
\hline (Andersen, Lillegaard et al. 2005) [57] & Parental education & & Self-reported & Overweight and obesity ${ }^{\mathrm{b}}$ \\
\hline (Kokkvoll, Jeppesen et al. 2012) [58] & & $\begin{array}{l}\text { Urban/rural. Parental } \\
\text { education, employment } \\
\text { and income level }\end{array}$ & Measured & Overweight and obesity ${ }^{\mathrm{b}}$ \\
\hline Lien, Kumar et al. 2007 a) [61] & $\begin{array}{l}\text { Parental education, income } \\
\text { and occupation }\end{array}$ & Residential area & Self-reported & Overweight and obesity ${ }^{\mathrm{b}}$ \\
\hline (Lien, Kumar et al. 2007b) [62] & Parental education & & Self-reported & Overweight and obesity ${ }^{\mathrm{b}}$ \\
\hline (Groholt, Stigum et al. 2008) [63] & $\begin{array}{l}\text { Educational plans } \\
\text { Family economy }\end{array}$ & & Self-reported & Overweight and obesity ${ }^{\mathrm{b}}$ \\
\hline (Grydeland, Bergh et al. 2012) [64] & Parental education & & Measured & Overweight and obesity ${ }^{\mathrm{b}}$ \\
\hline (Bjelland, Lien et al. 2010) [65] & Parental education & & Measured & $\begin{array}{l}\text { Waist-circumference } \\
\text { Overweight and obesity }\end{array}$ \\
\hline (Kristiansen, Juliusson et al. 2013) [66] & Parental education & & Measured & Overweight and obesity ${ }^{\mathrm{b}}$ \\
\hline (Steingrímsdottir, Olafsdottir et al. 2010) [71] & $\begin{array}{l}\text { Education } \\
\text { Urban/rural }\end{array}$ & & Self-reported & Obesity $^{\mathrm{a}}$ \\
\hline (Eidsdottir, Kristjansson et al. 2013) [74••] & Parental education & & Self-reported & Overweight and obesity ${ }^{\mathrm{a}, \mathrm{b}}$ \\
\hline (Thorisdottir, Kristjansson et al. 2012) [75] & & Urban/rural & Self-reported & Overweight and obesity ${ }^{\mathrm{b}}$ \\
\hline (Stamatakis, Zaninotto et al. 2010) [77] & Parental occupational status & & Measured & Overweight and obesity ${ }^{\mathrm{b}}$ \\
\hline
\end{tabular}

${ }^{a}$ Overweight and obesity corresponding to BMI $\geq 25 \mathrm{~kg} / \mathrm{m} 2$ and $30 \mathrm{~kg} / \mathrm{m} 2$, respectively. WHO (2000) Obesity: preventing and managing the global epidemic. Report of a WHO consultation

${ }^{\mathrm{b}}$ Cole TJ, Bellizzi MC, Flegal KM, et al. Establishing a standard definition for child overweight and obesity worldwide: international survey. BMJ2000; 320:1240-3

disadvantage" [90], p 28. Food insecurity, being closely linked to SEP, may operate in different pathways to accumulate adipose tissue [91]. For instance, Pierre Bourdieu's concept of habitus, meaning ".... a set of dispositions, internal to the individual, that both reflects external social structures and shapes how the individual perceives the world and act in it" [92], p 48 has also been suggested as an explanatory factor for differences in prevalence between groups of different SEP [83]. Life-circumstances such as childbirth may affect body weight development differently during varying societal conditions [93]. Since obesity in itself may lead to lower socioeconomic attainment [94] there is also a reverse causation.

\section{Changing Social Gradient across Nordic Countries and Implications for Action}

Inequality, measured by the Gini coefficient, seems to have increased in the Nordic region. The development of relative poverty in recent years is inconsistent (Table 1) but it may be problematic to assess allocation of resources from this measurement. For example, the Icelandic bank collapse in 2008, which brought a steeper gradient in food habits between people experiencing difficulties in "making ends meet" and others (Steingrimsdottir, oral presentation Nordic Nutrition Conference 2012), does not seem to be reflected in relative poverty.

Societal structures may influence prevalence of obesity in several ways. Economies in at least some of the Nordic countries are changing towards a less regulated marketliberalism. This is suggested to increase the risk of obesity on a population-level by the "fast food shock" acting more powerfully in such economies, in addition to a more stressful life [6]. Certain sectors of the food industry together with the slimming industry earn considerable amounts from the high obesity prevalence. The contradictory interests between these actors and public health issues are expressed in the debate on limits for advertisement, especially to children [95]. Reduced willingness from the wealthier groups in the population to spend money on social goods is a suggested mediator between income inequality and self-rated poor health [96].

The Nordic welfare systems, including highly relevant components like maternity health care, well-baby clinics and school health care, together with relatively well-educated populations, seem to have provided some protection also for 
those in low SEP. An example is the STOPP intervention in Sweden, working through schools, where children from parents with low education seemed to benefit the most in terms of improved food habits [97]. Findings presented in this review do not show any consistent trend for an increased social gradient. However, increased inequality and worsened societal economy may lead to poorer pre-requisites to flatten the gradient out.

Obesity is a chronic disease with only a few, expensive, options for effective treatment. Prevention is thus considered to be the most practicable way to decrease the prevalence. From a public health perspective a flattening out of the social gradient should preferably happen through diminishing prevalence in the groups with highest prevalence. If the environment contains obesogenic elements to such an extent that genetically predisposed people [98] are dependent on certain socioeconomically related resources to avoid the disease; then a reasonable measure to take is to make such resources commonly available. Infrastructure and legislation concerning these resources should be considered from an obesity prevention perspective. Societal means to support people with increased risk for OWOB should be reinforced. Interventions that increase health overall tend to widen health inequity within populations [99]. The same seems to be true also for obesity-prevention [100,101]; however, interventions in public schools have a potential to counteract health inequality [97]; mediated, e.g. by school nurses [102]. Allowing and encouraging people from groups with the largest prevalence to have an impact on planning, performance and evaluation of interventions can contribute to flattening the social gradient [103].

\section{Conclusion}

In the Nordic countries, social inequality in OWOB is present and persistent for adults, adolescents and children. There is some interaction between gender and SEP. Increased inequality within the countries might imply a risk for a steepened social gradient; however there is no consistent evidence for such development. Reasons for the inconsistency may include-beside the time-factor and the complexity of the etiology- lack of measured data on national levels, difficulties in choosing relevant assessment of SEP and/or successful societal efforts to counteract the epidemic. Studies that use measured data and cautiously chosen categories, and that succeed in improving participation rates, are desirable for future development of knowledge in the field. Opportunities to cope with OWOB as a public health problem include policy changes, keeping and reinforcing societal means to support groups and individuals with the highest prevalence, and to launch interventions that are adapted for and by the targeted groups.
In conclusion; although the Nordic countries have socially egalitarian ideals and a reputation for low levels of inequality, social differences remain. These appear to contribute to a persistent socioeconomic gradient in obesity. Although there is some sign that the Gini coefficient is worsening in Nordic countries, the available Nordic literature does not consistently show a widening social gap in the obesity epidemic. It may be speculated that positive features of the Nordic welfare states, coupled with their relative affluence, have contributed to the stable magnitude of this persistent social gap.

Acknowledgments This work was supported in part by the FAS EpiLife Research Center and the EpiLife-Teens Research program. The authors thank Associate Professor Marjaana Lahti-Koski for valuable comments. Maria Magnusson is supported by Public Health Secretariat, Western Sweden.

\section{Compliance with Ethics Guidelines}

Conflict of Interest Maria Magnusson, Thorkild I. A. Sørensen, Steingerdur Olafsdottir, Susanna Lehtinen-Jacks, Turid Lingaas Holmen, Berit Lilienthal Heitmann, and Lauren Lissner declare that they have no conflict of interest.

Human and Animal Rights and Informed Consent This article does not contain any studies with human or animal subjects performed by any of the authors.

\section{References}

Papers of particular interest, published recently, have been highlighted as:

- Of importance

•. Of major importance

1. Goldblatt PB, Moore ME, Stunkard AJ. Social factors in obesity. JAMA: J Am Med Assoc. 1965;192:1039-44.

2. Stunkard A, d'Aquili E, Fox S, Filion RD. Influence of social class on obesity and thinness in children. JAMA: J Am Med Assoc. 1972;221(6):579-84.

3. Shrewsbury V, Wardle J. Socioeconomic status and adiposity in childhood: a systematic review of cross-sectional studies 1990 2005. Obesity (Silver Spring). 2008;16(2):275-84.

4. Sobal J, Stunkard AJ. Socioeconomic status and obesity: a review of the literature. Psychol Bull. 1989;105(2):260-75.

5. Popkin BM, Gordon-Larsen P. The nutrition transition: worldwide obesity dynamics and their determinants. Int J Obes Relat Metab Disord: J Int Assoc Study of Obes. 2004;28 Suppl 3:S2-9.

6. Offer A, Pechey R, Ulijaszek S. Obesity under affluence varies by welfare regimes: the effect of fast food, insecurity, and inequality. Econ Hum Biol. 2010;8:297-308.

7. Knai C, Lobstein T, Darmon N, Rutter H, McKee M. Socioeconomic patterning of childhood overweight status in Europe. Int J Environ Res Public Health. 2012;9:1472-89.

8. Eurostat. Gini coefficient of equivalised disposable income (source: SILC). http://epp.eurostat.ec.europa.eu/tgm/table.do? tab=table\&language $=$ en $\&$ pode $=$ tessi 190 . 
9. Eurostat. At-risk-of-poverty rate after social transfers, 2009-2011 (\%).png. http://epp.eurostat.ec.europa.eu/statistics_explained/index. php?title=File:At-risk-of-poverty rate after social transfers, 2009-2011_(\%25).png\&filetimestamp=20130522202623. Accessed Sept 42013.

10. Rasmussen LB, Andersen LF, Borodulin K, Enghard Barbieri H, Fagt S, Matthiessen J et al. Nordic monitoring of diet, physical activity and overweight. First collection of data in all nordic countries 2011. TemaNord 2012.

11. WHO. Overweight/obesity 2008. http:/gamapserver.who.int/gho/ interactive charts/ncd/risk factors/overweight obesity/atlas. $\mathrm{html}$ ?indicator $=\mathrm{i} 1 \&$ date $=$ Both\%20sexes. Accessed 5 sept 2013.

12. Lissner L. Psychosocial aspects of obesity: individual and societal perspectives. Scand J Nutr. 1997;41:75-9.

13. Sundquist J, Johansson SE, Sundquist K. Levelling off of prevalence of obesity in the adult population of Sweden between 2000/01 and 2004/05. BMC Public Health. 2010;10:119. doi:10. 1186/1471-2458-10-119.

14. Strandhagen E, Berg C, Lissner L, Nunez L, Rosengren A, Toren $\mathrm{K}$, et al. Selection bias in a population survey with registry linkage: potential effect on socioeconomic gradient in cardiovascular risk. Eur J Epidemiol. 2010;25(3):163-72. doi:10.1007/s10654-0109427-7. This study demonstrates that non-participation is a likely source of bias in studies describing social disparities in health. A positive association between education level and frequent alcohol consumption was found to in part be explained by such bias. For other risk factors studied, an underestimation of the importance of low socioeconomic status was considered to be more likely.

15. Sjöberg A, Moraeus L, Yngve A, Poortvliet E, Al-Ansari U, Lissner L. Overweight and obesity in a representative sample of schoolchildren - exploring the urban-rural gradient in Sweden. Obes Rev: Off J Int Assoc Study Obes. 2011;12(5):305-14. doi: 10.1111/j.1467-789X.2010.00838.x.

16. Moraeus L, Lissner L, Yngve A, Poortvliet E, Al-Ansari U, Sjoberg A. Multi-level influences on childhood obesity in Sweden: societal factors, parental determinants and child's lifestyle. Int J Obes (2005). 2012;36(7):969-76. doi:10.1038/ijo. 2012.79.

17. Bammann K, Gwozdz W, Lanfer A, Barba G, De Henauw S, Eiben G, et al. Socioeconomic factors and childhood overweight in Europe: results from the multi-centre IDEFICS study. Pediatr Obes. 2013;8(1):1-12. doi:10.1111/j.2047-6310.2012.00075.x.

18. Lissner L, Johansson SE, Qvist J, Rossner S, Wolk A. Social mapping of the obesity epidemic in Sweden. Int J Obes Relat Metab Disord: J Int Assoc Study Obes. 2000;24(6):801-5.

19. Eiben G, Dey DK, Rothenberg E, Steen B, Björkelund C, Bengtsson C, et al. Obesity in 70-year-old Swedes: secular changes over 30 years. Int J Obes (2005). 2005;29(7):810-7.

20. Sundblom E, Petzold M, Rasmussen F, Callmer E, Lissner L. Childhood overweight and obesity prevalences levelling off in Stockholm but socioeconomic differences persist. Int J Obes (2005). 2008.

21. Sjöberg A, Lissner L, Albertsson-Wikland K, Mårild S. Recent anthropometric trends among Swedish school children: evidence for decreasing prevalence of overweight in girls. Acta Paediatr. 2008;97(1):118-23.

22. Magnusson MB, Sjöberg A, Kjellgren KI, Lissner L. Childhood obesity and prevention in different socio-economic contexts. Prev Med. 2011

23. Due P, Heitmann B, Sørensen TIA. Prevalence of obesity in Denmark. Obes Rev: Off J Int Assoc Study Obes. 2007;8(3): 187-9.

24. Heitmann BL, Stroger U, Mikkelsen KL, Holst C, Sørensen TIA. Large heterogeneity of the obesity epidemic in Danish adults. Public Health Nutr. 2004;7(3):453-60. doi:10.1079/ phn2003542.
25. Sundhedsstyrelsen. Den nationale sundhedsprofil 2010: Sundhedsstyrelsen 2011.

26. Jensen HN GC, Jørgensen T. Udvikling i risikofaktorer for hjertekarsygdom i Vestegnskommunerne 1978-2006. s. 31. Glostrup, Danmark2008.

27. Larsen AM, Lund R, Kriegbaum M, Avlund K, Osler M. Childhood social circumstances and body mass index in adult life: the Metropolit 1953 Danish male birth cohort. Scand J Public Health. 2011;39(3):296-302. doi:10.1177/ 1403494811399654.

28. Groth MV, Fagt S, Stockmarr A, Matthiessen J, Biltoft-Jensen A. Dimensions of socioeconomic position related to body mass index and obesity among Danish women and men. Scand J Public Health. 2009;37(4):418-26. doi:10.1177/1403494809105284.

29. Morgan C, Mortensen L, Rasmussen M, Andersen A, Sørensen TIA, Due P. Parental socioeconomic position and development of overweight in adolescence: longitudinal study of Danish adolescents. BMC Public Health. 2010;29(10):520.

30. Krue S, Coolidge J. The prevalence of overweight and obesity among Danish school children. Obes Rev: Off J Int Assoc Study Obes. 2010;11(7):489-91.

31. Aarup M, Sokolowski I, Lous J. The prevalence of obesity and overweight among 3 year-old children in the municipality of Aalborg and identification of risk factors Ugeskr Laeger[Article in Danish]. 2008;170(6):452-6.

32. Pietinen P, Vartiainen E, Mannisto S. Trends in body mass index and obesity among adults in Finland from 1972 to 1992. Int J Obes Relat Metab Disord: J Int Assoc Study Obes. 1996;20(2):114-20.

33. Lahti-Koski M, Vartiainen E, Mannisto S, Pietinen P. Age, education and occupation as determinants of trends in body mass index in Finland from 1982 to 1997. Int J Obes Relat Metab Disord: J Int Assoc Study Obes. 2000;24(12):1669-76.

34. Lahti-Koski M, Harald K, Saarni S, Peltonen M, Männistö S. Changes in body mass index and measures of abdominal obesity in Finnish adults between 1992 and 2006, the National FINRISK Study Clinical. Obesity. 2012;2:57-63.

35. Männistö S, Laatikainen T, Vartiainen E. "Obesity in Finlandresults from the FINRISK studies 1972-2012". (In Finnish). Available at: http:/www.julkari.fi/bitstream/handle/10024/90885/ TutkimuksestaTiiviisti4_lihavuus.pdf?sequence=1. 2012 .

36. Sarlio-Lahteenkorva S, Lahelma E. The association of body mass index with social and economic disadvantage in women and men. Int J Epidemiol. 1999;28(3):445-9.

37.•• Prättälä R, Sippola R, Lahti-Koski M, Laaksonen MT, Mäkinen T, Roos E. Twenty-five year trends in body mass index by education and income in Finland. BMC Public Health. 2012;12:936. doi:10. 1186/1471-2458-12-936. In this study, an interesting observation was made that while there were no overall change in the educational and income differences of BMI in Finland between 1978 and 2002, income differences in men varied according to their educational level. The authors "encourage further research on the pathways between income,education, living conditions and the increasing BMI".

38. Sulander TT, Uutela AK. Obesity and education: recent trends and disparities among 65- to 84-year-old men and women in Finland. Prev Med. 2007;45(2-3):153-6. doi:10. 1016/j.ypmed.2007.02.008.

39. Jokela M, Kivimäki M, Elovainio M, Viikari J, Raitakari O, Keltikangas-Järvinen L. Urban/rural differences in body weight: evidence for social selection and causation hypotheses in Finland. Soc Sci Med (1982). 2009;68(5):867-75.

40. Lahti-Koski M, Taskinen O, Similä M, Männistö S, Laatikainen T, Knekt $\mathrm{P}$, et al. Mapping geographical variation in obesity in Finland. Eur J Public Health. 2008;18(6):637-43.

41. Kautiainen S, Koivisto AM, Koivusilta L, Lintonen T, Virtanen SM, Rimpela A. Sociodemographic factors and a secular trend of 
adolescent overweight in Finland. Int J Pediatr Obes. 2009;4(4): 360-70.

42. Vuorela N, Saha MT, Salo MK. Change in prevalence of overweight and obesity in Finnish children - comparison between 1974 and 2001. Acta Paediatr. 2011;100(1):109-15. doi:10.1111/ j.1651-2227.2010.01980.x.

43. THL. Health and well-being inequalities among children and their families. National institute for health and wellfare (THL) (In Finnish). Available at: http://www.thl.fi/thl-client/pdfs/b79b33f7e767-4a74-ab5d-40e9b60a1fe8 2012.

44. Koivusilta LK, Rimpela AH, Kautiainen SM. Health inequality in adolescence. Does stratification occur by familial social background, family affluence, or personal social position? BMC Public Health. 2006;6:110.

45. Lahti-Koski M, Seppänen-Nuijten E, Männistö S, Harkanen T, Rissanen H, Knekt P, et al. Twenty-year changes in the prevalence of obesity among Finnish adults. Obes Rev: Off J Int Assoc Study Obes. 2010;11(3):171-6. doi:10.1111/j.1467-789X.2009.00681.x.

46. Meyer HE, Tverdal A. Development of body weight in the Norwegian population. Prostaglandins, leukotrienes, and essential fatty acids. 2005;73(1):3-7. doi:10.1016/j.plefa.2005.04.003.

47. Jacobsen BK, Njolstad I, Thune I, Wilsgaard T, Lochen ML, Schirmer H. Increase in weight in all birth cohorts in a general population: the Tromso study, 1974-1994. Arch Intern Med. 2001;161(3):466-72.

48. Midthjell K, Lee CM, Langhammer A, Krokstad S, Holmen TL, Hveem K, et al. Trends in overweight and obesity over 22 years in a large adult population: the HUNT Study, Norway. Clin Obes. 2013;3(1-2):12-20. doi:10.1111/cob.12009.

49. Tverdal A. [Prevalence of obesity among persons aged 40 42 years in two periods] (In Norwegian). Tidsskrift for den Norske laegeforening: tidsskrift for praktisk medicin, ny raekke. 2001;121(6):667-72.

$50 . \bullet$ Krokstad S, Erntsen L, Sund E, Bjørngaard J, Langhammer A, Midthjell K, et al. Social and spatial patterns of obesity diffusion over three decades in a Norwegian county population. The HUNT Study. BMC Public Health. 2013;13(1): 973. This study includes men and women 30-69 yrs from the three surveys of the HUNT study (1984-06, 1995-97 and 2006-08) with a little more than 40.000 people in each wave. The relative SEP inequalities of obesity did not change significantly, but the differences in absolute prevalence of obesity between the low and the high educational group have increased during these 20 years.

51. Strand BH, Tverdal A. Trends in educational inequalities in cardiovascular risk factors: a longitudinal study among 48.000 middle-aged Norwegian men and women. Eur J Epidemiol. 2006;21(10):731-9.

52. Norwegian Institute of Public Health. Facts about overweight and obesity. http://www.fhi.no. Accessed Aug 152013.

53. WHO. Evaluation of the Norwegian nutrition policy with a focus on the Action Plan on Nutrition 2007-2011. 2013.

54. Dvergsnes K, Skeie G. Utviklingen i kropsmasseindeks hos firåringer I Tromsø 1980-2005. (Development of body mass index in 4 years old in Tromsø, Norway). Tidsskr Nor Legefoen. 2009;129:13-6.

55. Juliusson PB, Roelants M, Eide GE, Hauspie R, Waaler PE, Bjerknes R. Overweight and obesity in Norwegian children: secular trends in weight-for-height and skinfolds. Acta Paediatr. 2007;96(9):1333-7. doi:10.1111/j.1651-2227.2007.00421.x.

56. Kolle E, Steene-Johannessen J, Holme I, Andersen LB, Anderssen SA. Secular trends in adiposity in Norwegian 9-year-olds from 1999-2000 to 2005. BMC Public Health. 2009;9:389. doi:10. 1186/1471-2458-9-389.

57. Andersen LF, Lillegaard IT, Overby N, Lytle L, Klepp KI, Johansson L. Overweight and obesity among Norwegian schoolchildren: changes from 1993 to 2000. Scand J Public Health. 2005;33(2): 99-106. doi:10.1080/140349404100410019172.

58. Kokkvoll A, Jeppesen E, Juliusson PB, Flaegstad T, Njolstad I. High prevalence of overweight and obesity among 6-year-old children in Finnmark County, North Norway. Acta Paediatr. 2012;101(9):924-8. doi:10.1111/j.1651-2227.2012.02735.x.

59. Bjornelv S, Lydersen S, Mykletun A, Holmen TL. Changes in BMI-distribution from 1966-69 to 1995-97 in adolescents. The Young-HUNT study, Norway. BMC Public Health. 2007;7:279.

60. HUNT. Public health development, The HUNT Study Norway, HUNT1 (1984-86)-HUNT2 (1995-97)-HUNT3 (2006-08). HUNT Forskningssenter 2011, ISBN 978-82-91725-08-6.

61. Lien N, Kumar BN, Lien L. [Overweight among adolescents in Oslo] (in Norwegian). Tidsskrift for den Norske laegeforening: tidsskrift for praktisk medicin, ny raekke. 2007a;127(17):2254-8.

62. Lien N, Kumar BN, Holmboe-Ottesen G, Klepp KI, Wandel M. Assessing social differences in overweight among 15- to 16-yearold ethnic Norwegians from Oslo by register data and adolescent self-reported measures of socio-economic status. Int $\mathrm{J}$ Obes (2005). 2007;31(1):30-8. doi:10.1038/sj.ijo.0803415.

63. Groholt EK, Stigum H, Nordhagen R. Overweight and obesity among adolescents in Norway: cultural and socio-economic differences. J Public Health (Oxf). 2008;30(3):258-65.

64. Grydeland M, Bergh IH, Bjelland M, Lien N, Andersen LF, Ommundsen Y, et al. Correlates of weight status among Norwegian 11-year-olds: the HEIA study. BMC Public Health. 2012;12:1053. doi:10.1186/1471-2458-12-1053.

65. Bjelland M, Lien N, Bergh IH, Grydeland M, Anderssen SA, Klepp KI, et al. Overweight and waist circumference among Norwegian 11-year-olds and associations with reported parental overweight and waist circumference: the HEIA study. Scand J Public Health. 2010;38(5 Suppl):19-27. doi:10.1177/ 1403494810385036.

66. Kristiansen H, Juliusson PB, Eide GE, Roelants M, Bjerknes R. TV viewing and obesity among Norwegian children: the importance of parental education. Acta Paediatr. 2013;102(2):199-205. doi:10.1111/apa.12066.

67. Nilsen S, Krokstad S, Holmen T, Westin S. Adolescents' healthrelated dietary patterns by parental socio-economic position, the Nord-Trøndelag Health Study (HUNT). Eur J Public Health. 2010;20(3):299-305.

68. Heyerdahl N, Aamodt G, Nordhagen R, Hovengen R. [Overweight children-how important is the urban/rural factor?] (In Norwegian). Tidsskrift for den Norske laegeforening: tidsskrift for praktisk medicin, ny raekke. 2010;132(9):1080-3.

69. Valdimarsdottir M, Jonsson SH, Thorgeirsdottir H, Gisladottir E, Gudlaugsson JO, Thorlindsson T. Body weight and weight condition of adult Icelanders from 1990 to 2007. [in Icelandic]. Reykjavík: Directorate of Health.2009.

70. Thorgeirsdottir H, Valgeirsdottir H, Gunnarsdottir I, Gisladottir E, Gunnarsdottir BE, Thorsdottir I, et al. The diet of Icelanders. National nutrition survey 2010-2011. Main results. [in Icelandic]. Reykjavík: Directorate of Health, Icelandic Food and Veterinary Authority, Unit for Nutrition Research at University of Iceland.2011.

71. Steingrimsdottir L, Olafsdottir EJ, Jonsdottir LS, Sigurdsson R, Tryggvadottir L. Smoking, obesity and education of Icelandic women by rural-urban residence [in Icelandic]. Icel Med J. 2010;96:259-64.

72. Steingrimsdottir L, Thorgeirsdottir H, Olafsdottir AS. The diet of Icelanders. Dietary survey of The Icelandic Nutrition Council 2002. Main findings. [in Icelandic]. Reykjavík: The Icelandic Nutrition Council; 2002.

73. Jonsson SH, Hedinsdottir M, Erlendsdottir RO, Gudlaugsson JO, Danielsdottir S, Reynisson JA. Body weight of children in the 
capital area. [in Icelandic]. Reykjavík: Directorate of Health, Primary Health care of the Capital Area; 2013.

74.• Eidsdottir S, Kristjansson A, Sigfusdottir ID, Garber CE, Allegrante JP. Secular trends in overweight and obesity among Icelandic adolescents: do parental education levels and family structure play a part? Scand J Public Health. 2013;41(4):384-91. doi:10.1177/1403494813477927. Representative data from 70 $80 \%$ of the total population in the age group 16-20 years. The results demonstrate that adolescents with low-educated parents were consistently overrepresented among those with overweight and obesity across all four survey years, and that the gap in overweight and obesity between the high-and low-educated subgroups increased over time.

75. Thorisdottir I, Kristjansson A, Sigfusdottir I, Allegrante J. The landscape of overweight and obesity in Icelandic adolescents: geographic variation in body-mass index between 2000 and 2009. J Community Health. 2012;37:234-41.

76. Ball K, Crawford D. Socioeconomic status and weight change in adults: a review. Soc Sci Med (1982). 2005;60(9):1987-2010.

77. Stamatakis E, Zaninotto P, Falaschetti E, Mindell J, Head J. Time trends in childhood and adolescent obesity in England from 1995 to 2007 and projections of prevalence to 2015. J Epidemiol Community Health. 2010;64:167-74.

78. Geyer S, Hemström O, Peter R, Vagerö D. Education, income, and occupational class cannot be used interchangeably in social epidemiology. Empirical evidence against a common practice. J Epidemiol Community Health. 2006;60(9):804-10.

79. Rosendahl KI, Sundblom E, Schäfer EL. Trajectories of weight disturbances during adolescence in relation to gender in a Swedish cohort. Acta Paediatr. 2012;101:300-7.

80. Connor Gorber S, Tremblay M, Moher D, Gorber B. A comparison of direct vs. self-report measures for assessing height, weight and body mass index: a systematic review. Obes Rev: Off J Int Assoc Study Obes. 2007;8(4):307-26.

81. Boström G, Diderichsen F. Socioeconomic differentials in misclassification of height, weight and body mass index based on questionnaire data. Int J Epidemiol. 1997;26(4):860-6.

82. Hayes AJ, Clarke PM, Lung TW. Change in bias in self-reported body mass index in Australia between 1995 and 2008 and the evaluation of correction equations. Popul Health Metrics. 2011;9: 53. doi:10.1186/1478-7954-9-53.

83. McLaren L. Socioeconomic status and obesity. Epidemiol Rev. 2007;29:29-48. doi:10.1093/epirev/mxm001.

84. Renzaho AM. Fat, rich and beautiful: changing socio-cultural paradigms associated with obesity risk, nutritional status and refugee children from sub-Saharan Africa. Health Place. 2004;10(1):105-13.

85. Egger G, Swinburn B. An "ecological" approach to the obesity pandemic. Br Med J. 1997;315(7106):477-80.

86. Lobstein T, Dibb S. Evidence of a possible link between obesogenic food advertising and child overweight. Obes Rev: Off J Int Assoc Study Obes. 2005;6(3):203-8.

87. Rydén PJ, Hagfors L. Diet cost, diet quality and socio-economic position: how are they related and what contributes to differences in diet costs? Public Health Nutr. 2011;14(9):1680-92. doi:10. 1017/s1368980010003642.
88. Rao M, Afshin A, Singh G, Mozaffarian D. Do healthier foods and diet patterns cost more than less healthy options? A systematic review and meta-analysis. BMJ Open. 2013;3:e04277.

89. Maillot M, Darmon N, Drewnowski A. Are the lowest-cost healthful food plans culturally and socially acceptable? Public Health Nutr. 2010;13(8):1178-85. doi:10.1017/s1368980009993028.

90. Brunner EJ, Marmot M. Social organization, stress and health. In: Marmot M, Wilkinson R, editors. Social determinants of health. Oxford: Oxford University Press; 2001.

91. Sørensen TIA. Is obesity a healthy active response to an expected futire lack of energy rather than a passive storage of surplus energy? Obes Facts. 2012;5:431-5.

92. Power E. An introduction to Pierre Bourdieu's key theoretical concepts. J Study Food Soc. 1999;3(1):48-52.

93. Lopez-Arana S, Burdorf A, Avendano M. Trends in overweight by educational level in 33 low- and middle-income countries: the role of parity, age at first birth and breastfeeding. Obes Rev: Off J Int Assoc Study Obes. 2013. doi:10.1111/obr.12051.

94. Sonne-Holm S, Sørensen TIA. Prospective study of attainment of social class of severely obese subjects in relation to parental social class, intelligence, and education. Br Med J (Clinical research ed). 1986;292(6520):586-9.

95. Harris JL, Pomeranz JL, Lobstein T, Brownell KD. A crisis in the marketplace: how food marketing contributes to childhood obesity and what can be done. Annu Rev Public Health. 2009;30:211-25. doi:10.1146/annurev.publhealth.031308.100304.

96. Rostila M, Kolegard ML, Fritzell J. Income inequality and self-rated health in Stockholm, Sweden: a test of the 'income inequality hypothesis' on two levels of aggregation. Soc Sci Med (1982). 2012;74(7):1091-8. doi:10.1016/j.socscimed. 2011.11.027.

97. Marcus C, Nyberg G, Nordenfelt A, Karpmyr M, Kowalski J, Ekelund U. A 4-year, cluster-randomized, controlled childhood obesity prevention study: STOPP. Int J Obes (Lond). 2009;33(4): 408-17.

98. Loos RJ, Bouchard C. Obesity-is it a genetic disorder? J Intern Med. 2003;254(5):401-25.

99. White M, Adams J, Heywood P. How and why do interventions that increase health overall widen inequalities within populations? In: Babones SJ, editor. Social inequality and public health. Bristol: The Policy Press; 2009.

100. WHO. Population-based prevention strategies for childhood obesity:report of a WHO forum and technical meeting, Geneva, 1517 December 2009: World Health Organization; 2010.

101. Plachta-Danielzik S, Pust S, Asbeck I, Czerwinski-Mast M, Langnase K, Fischer C, et al. Four-year follow-up of schoolbased intervention on overweight children: the KOPS study. Obesity (Silver Spring). 2007;15(12):3159-69.

102. Borup I, Holstein B. Social class variations in schoolchildren's self-reported outcome of the health dialogue with the school health nurse. Scand J Caring Sci. 2004;18:343-50.

103. Economos CD, Hyatt RR, Must A, Goldberg JP, Kuder J, Naumova EN, et al. Shape up Somerville 2-year results: a community-based environmental change intervention sustains a BMI z-score decrease in children. Prev Med. 2013. doi:10.1016/j. ypmed.2013.06.001. 